\title{
FOSFOTIROSINA FOSFATASA SHP-1, SOMATOSTATINA Y CÁNCER DE PRÓSTATA
}

\author{
P.D. ZAPATA, B. COLAS, P. LÓPEZ-RUIZ, R.M. ROPERO, R.M. MARTÍN, \\ F.J. RODRÍGUEZ, F.J. GONZÁLEZ, J.I. LÓPEZ, J.C. ANGULO

\begin{abstract}
Departamento de Bioquímica. Departamento de Cirugía. Universidad de Alcalá. Servicio de Urología. Hospital Príncipe de Asturias. Alcalá de Henares. Madrid.

Servicio de Anatomía Patológica. Hospital de Basurto. Bilbao.
\end{abstract}

Actas Urol Esp. 28 (4): 269-285, 2004

\section{RESUMEN}

FOSFOTIROSINA FOSFATASA SHP-1, SOMATOSTATINA Y CÁNCER DE PRÓSTATA

Revisamos los mecanismos de control de crecimiento prostático basados en andrógenos y productos de secreción neuroendocrina, prestando especial atención al papel de la somatostina (SS) como inhibidor del crecimiento neoplásico. Las aportaciones de nuestro grupo confirman que este efecto antiproliferativo de la SS sobre la próstata está mediado por la fosfotirosina fosfatasa SHP-1, presente en la próstata humana. Esta enzima juega un papel en el control de la proliferación celular prostática y en la progresión del cáncer de próstata. Además, pensamos que su presencia podría determinar el potencial terapéutico de la SS en el control del cáncer de próstata.

PALABRAS CLAVE: Neoplasia prostática. Proteína tirosina fosfatasa. SHP-1. Somatostatina. Célula neuroendocrina. Próstata.

\section{ABSTRACT}

PHOSPHOTYROSINE PHOSPHATASE SHP-1, SOMATOSTATIN AND PROSTATE CANCER

We review the mechanisms involved in prostatic growth based on androgens and product of neuroendocrine secretion, with special reference to the role of somatostatin (SS) in the inhibition of neoplastic growth. Our contributions in the field confirm the antiproliferative effect of SS on the prostate is mediated by phosphotyrosine phosphatase SHP- 1 , that is present in human prostate. This enzyme plays a role in the control of prostatic cell proliferation and in the progression of prostate cancer. Besides, we consider its presence may determine the therapeutic potential of SS in the control of prostate cancer.

KEY WORDS: Prostate neoplasm. Protein tyrosin phosphatase. SHP-1. Somatostatin. Neuroendocrine cell. Prostate.

$\mathrm{D}$ esconocemos la totalidad de los factores responsables del desarrollo y de la progresión del cáncer de próstata. La experiencia adquirida con terapia hormonal basada en la deprivación androgénica, nos ha enseñado que pasado un tiempo se produce una reactivación del crecimiento del tumor, proceso que va acompañado de resistencia al tratamiento debido a la aparición de células que no responden a los andrógenos.
De hecho, cada vez resulta más evidente que la función prostática no sólo depende de andrógenos, sino que existen una gran diversidad de hormonas peptídicas, factores de crecimiento, bucles reguladores autocrinos/paracrinos e interacciones entre el epitelio y el estroma que controlan y mantienen el funcionamiento normal de la próstata y que están implicados en el desarrollo de sus enfermedades. 
A sí, la fase independiente de andrógenos es el centro de atención de la mayoría de las investigaciones actuales; investigaciones que intentan sentar las bases del desarrollo de nuevas terapias. En este sentido, sabemos que algunos péptidos, como la somatostatina (SS), poseen un claro potencial antimitogénico pero, lamentablemente, los datos preclínicos acerca de su utilización en el carcinoma prostático son contradictorios, probablemente debido al desconocimiento de los mecanismos moleculares a través de los cuales ejerce su acción biológica. Así, para entender el efecto antiproliferativo de la SS en el cáncer de próstata, es necesario conocer los subtipos expresados en la próstata normal y neoplásica, cuál de estos receptores es responsable del efecto antiproliferativo, y el mecanismo o mecanismos celulares utilizados. Es probable que en el momento que conozcamos las respuestas a estas preguntas se puedan realizar nuevos ensayos clínicos que valoren ciertamente la eficacia de la SS en el tratamiento de esta enfermedad.

\section{REGULACIÓN DEL CRECIMIENTO PROSTÁTICO}

El desarrollo de la próstata, y el del resto de las estructuras sexuales accesorias internas masculinas, depende de los andrógenos. La testosterona se sintetiza en las células de Leydig del testículo diariamente y se vierte al plasma. La esteroidogénesis testicular está controlada por el eje hipotálamo-hipofisiario. La liberación por el hipotálamo de la GnRH (hormona estimulante de gonadotropinas) estimula la secreción de la $\mathrm{LH}$ (hormona luteinizante) por la hipófisis, que va a controlar la secreción de testosterona a nivel testicular. Además de los andrógenos testiculares, llegan a la próstata andrógenos liberados por la glándula adrenal. Esta segunda fuente de andrógenos puede adquirir relevancia en situaciones de castración, aunque su importancia en la próstata normal y en el desarrollo y el tratamiento del cáncer y de la hiperplasia prostática benigna (HBP) sigue siendo tema de debate ${ }^{1}$.

Dada su naturaleza lipofílica, la testosterona se transporta en sangre unida a proteínas: 58\% por la globulina transportadora de hormonas sexuales (SHBG), 40\% por la albúmina, dejando sólo un $2 \%$ de hormona libre disponible para ser captada por los tejidos ${ }^{2}$. La fracción libre se verá afectada por variaciones en los niveles de los transportadores, modificando la cantidad disponible para la próstata. Situaciones como la obesidad, la edad, y el aumento de estrógenos o de la misma testosterona pueden producir estas variaciones $^{3}$.

Después de su internalización en la célula prostática la testosterona se transforma en dihidrotestosterona (DHT) por la enzima 5- $\alpha$-reductasa presente en el retículo endoplasmático rugoso $^{4}$. La DHT es 10 veces más activa que la testosterona. Así, la DHT se une a un receptor nuclear específico que, activará o reprimirá la expresión de determinados genes, regulando la funcionalidad celular. Determinados antiandrógenos pueden unirse al receptor de andrógenos, pero los cambios conformacionales inducidos no permiten que el receptor interaccione con el $\mathrm{ADN}^{5}$. La metabolización final de la DHT está a cargo de óxido reductasas que transforman la DHT primero en dioles y luego en trioles totalmente inactivos.

La forma en que los andrógenos controlan la proliferación y regulan la función prostática está siendo ampliamente estudiada. La DHT regula el crecimiento prostático, estimula la proliferación celular e inhibe la apoptosis o muerte celular programada. Una disminución de los niveles de DHT y de su receptor provoca involución de la próstata, mientras que su aumento inicia una proliferación celular activa, ambos procesos están asociados a una expresión génica específica ${ }^{5}$. Sin embargo, no existen pruebas suficientes de que la DHT estimule directamente la sintesis de ADN, más bien sus efectos estarían mediados por una serie de factores de crecimiento, cuya sintesis se vería estimulada por la $\mathrm{DHT}^{6}$. Los factores de crecimiento, por lo tanto, serían mediadores directos de la acción de los andrógenos y pueden ser responsables de mediar las interacciones entre el epitelio y el estroma ${ }^{7}$.

En condiciones normales los andrógenos y los factores de crecimiento crean un balance que regula el crecimiento, la diferenciación, la supervivencia y la muerte de células prostáticas. En la próstata se ha observado la acción de 4 familias de factores de crecimiento, producidos de manera 
local y que actúan de manera paracrina o autocrina en el estroma o en el epitelio: familia EGF (EGF y TGF- $\alpha$ ), familia TGF- $\beta$ (TGF- $\beta 1,2$ y 3 ), familia IGF (IGF-I, IGF-II, IGF-BP) y familia FGF (bFGF y KGF) ${ }^{8}$ (Fig. 1).

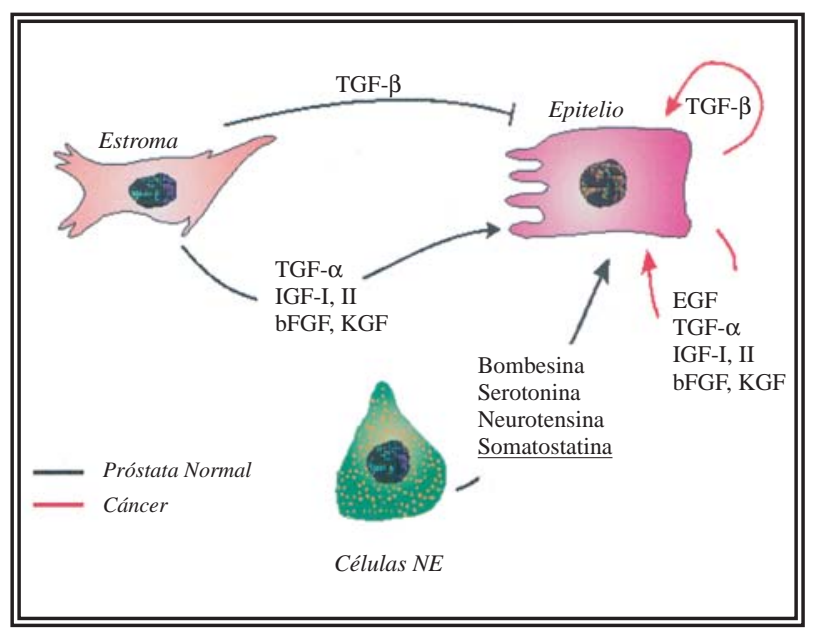

FIGURA 1. Factores de crecimiento que actúan en la próstata normal y en el cáncer. En la próstata normal flechas negras) los factores de crecimiento TGF $\alpha$, bFGF, KGF, IGF-I, IGF-II y TGF- $\beta$, secretados por el estroma, actúan de manera paracrina sobre sus receptores ubicados en el epitelio. El TGF $\alpha$, IGF-I, IGF-II, bFGF y KGF estimulan la proliferación de las células epiteliales, mientras que el TGF- $\beta$ la inhibe. Sin embargo, en el cáncer (flechas rojas) estos factores de crecimiento, secretados por el epitelio, actúan de manera autocrina sobre estas células. En este último caso, predominan los efectos mitogénicos porque disminuye la sensibilidad a los efectos inhibitorios del TGF- $\beta$, potenciándose sus efectos angiogénicos $y$ metastásicos.

Los niveles de andrógenos regulan, tanto en el epitelio como en el estroma, la secreción de los factores de crecimiento así como la expresión de sus receptores, creando un delicado equilibrio entre ambos compartimentos celulares. Durante el desarrollo del cáncer de próstata, este equilibrio se pierde alterándose la forma y lugar de secreción de los factores de crecimiento, así como la expresión de sus receptores y proteínas relacionadas, como algunos proto-oncogenes y genes supresores de tumores. Este estado promueve la invasión y la metástasis a sitios favorables para el desarrollo de la célula neoplásica. La terapia de supresión androgénica conlleva la selección de las células malignas, sobreviviendo aquellas capaces de crecer en ausencia de andrógenos. Se genera así la fase independiente de andrógenos de la enfermedad ${ }^{5}$. En este momento suceden diversas alteraciones moleculares ${ }^{9}$, las principales se reflejan en la Tabla I.

\section{CÉlULAS NEUROENDOCRINAS}

Las células neuroendocrinas (NE) de la próstata pertenecen al sistema denominado antiguamente como APUD (amine precursor uptake and decarboxylation). Estas células, componente minoritario del epitelio prostático, carecen del receptor de andrógenos y secretan gran variedad de péptidos, neuropéptidos y otras moléculas bioactivas. La mayoría de las células $\mathrm{NE}$ prostáticas secretan cromogranina A, enolasa específica de neuronas y serotonina. Además producen calcitonina, gonadotropina coriónica humana $\alpha$, péptido similar a la TSH, neurotensina, proteína relacionada con la PTH, colecistoquinina, bombesina y somatostatina ${ }^{10}$. Las células $\mathrm{NE}$, actuando de forma paracrina y/o autocrina regulan las secreciones exocrinas y endocrinas de células epiteliales y NE vecinas, así como la proliferación y diferenciación celular. Estas células presentan prolongaciones extendidas hacia el lumen de las glándulas que les permiten detectar cambios de $\mathrm{pH}$, concentración de proteínas, neuropéptidos u hormonas del contenido luminal, y a través de señales determinadas modificar o regular la secreción de las células exocrinas ${ }^{11}$.

\section{TABLA I}

ALTERACIONES MOLECULARES ASOCIADAS AL DESARROLLO DEL CARCINOMA DE PRÓSTATA

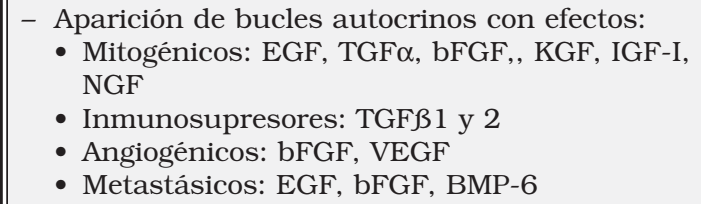

- Aparición de bucles autocrinos con efectos:

- Mitogénicos: EGF, TGF $\alpha$, bFGF,, KGF, IGF-I, NGF

- Inmunosupresores: TGF $\beta 1$ y 2

- Angiogénicos: bFGF, VEGF

- Metastásicos: EGF, bFGF, BMP-6

- Alteraciones en la expresión de proteínas de unión a IGF: IGFBP

- Incremento en la expresión de proto-oncogenes: EGFR, p185 ${ }^{\text {erbB-2}}, \mathrm{p} 160^{\text {erbB-3 }}$

- Disminución de productos supresores de tumores: TGFßRI, TGFßRII, IGFRII

- Alteraciones en la expresión de proteínas que regulan el balance muerte/proliferación celular: bcl-2, p2 $1^{\text {Cip } 1}$, p2 $7^{\text {Kip } 1}, \mathrm{p} 16, \mathrm{CDK}, \mathrm{CDC}$ 
En los últimos años las células NE han adquirido cierto protagonismo al observarse que más del $50 \%$ de los tumores de próstata, contienen células neoplásicas dispersas o formando focos, carentes de receptor de andrógenos y que presentan un fenotipo $\mathrm{NE}^{12}$. El número de estas células aumenta conforme el adenocarcinoma progresa hacia fases más avanzadas o resistentes a andrógenos. Estudios recientes parecen indicar que la diferenciación $\mathrm{NE}$ se correlaciona con un mal pronóstico, con la progresión del tumor y con la independencia androgénica ${ }^{10}$. Es posible que ligeros cambios en el microambiente celular faciliten la adquisición de un fenotipo NE por parte de ciertas células tumorales ${ }^{13}$. Los productos secretados por estas células, actuando de forma paracrina/autocrina, activan la proliferación de las células vecinas y facilitan el crecimiento independiente de andrógenos del tumor. De hecho se han observado células tumorales proliferando en la proximidad de focos de células $\mathrm{NE}^{14}$. Sin embargo, los resultados obtenidos al intentar establecer una estrecha relación entre diferenciación NE y avance del tumor, no son concluyentes $^{10}$.

Existen distintas poblaciones de células NE que varian en sus productos de secreción y en sus receptores. La producción de factores autocrinos/paracrinos por las células neuroendocrinas o por las células epiteliales tumorales diferenciadas a neuroendocrinas, está probablemente influenciado por hormonas y podría cumplir un papel importante en la progresión del cáncer. Sin embargo, son necesarios más estudios para evaluar correctamente la significación diagnóstica y terapéutica de la diferenciación neuroendocrina en el cáncer de próstata.

\section{LA SOMATOSTATINA}

Entre los factores sintetizados y liberados por las células NE prostáticas se encuentra la somatostatina. La somatostatina es un neuropéptido, de amplia distribución en el organismo, que inhibe una gran variedad de acciones fisiológicas, regulando la liberación de hormonas, péptidos y neurotransmisore ${ }^{15} \mathrm{y}$ actuando como un inhibidor endógeno del crecimiento ${ }^{16}$. Existen principalmente dos formas activas circulantes del péptido, una de 14 aminoácidos (la somatostatina
14) y otra de 28 (la somatostatina 28). Dada su corta vida media, que limita sus posibles aplicaciones in vivo, se han desarrollado análogos que se utilizan en clínica: el octreotide (SMS 201995), el lanreotide (BIM 23014) y el vapreotide (RC 160) ${ }^{17}$.

Todas las acciones de la somatostatina pasan por la unión del péptido a receptores presentes en las membranas de las células. Estos receptores pertenecen a la clase de receptores acoplados a proteínas G y presentan siete dominios transmembrana. En la actualidad se conocen cinco subtipos de receptores denominados sstr1, sstr2, sstr3, sstr4 y sstr5 ${ }^{18,19}$. Cada uno de estos subtipos presenta un perfil farmacológico específico y se encuentran asociados a diferentes sistemas de transducción de señales: adenilato ciclasa, canales iónicos, guanilato ciclasa, fosfolipasa $\mathrm{C}$, fosfolipasa $A_{2}$, MAP quinasa, serin-treonin fosfatasas y tirosinas fosfatasas ${ }^{19}$

La somatostatina es uno de los pocos neuropéptidos que inhibe la proliferación celular, in vitro e in vivo, de múltiples líneas celulares $\mathrm{y}$ tumores experimentales. In vitro, este efecto antiproliferativo depende de la presencia de receptores para la SS en las células tratadas. Sin embargo, in vivo, la situación es diferente. La SS o sus análogos pueden inhibir la proliferación de tumores que carecen de receptores para este péptido. Esta observación ha permitido distinguir entre efectos antiproliferativos directos de la SS mediados por receptores ubicados en las células tumorales- y efectos indirectos -mediados por receptores ubicados en células no tumorales-. En estos últimos, la SS inhibe la secreción de factores de crecimiento, como el IGF-I, y de otras hormonas tróficas que actúan sobre las células tumorales ${ }^{20}$ (Fig. 2).

Por lo tanto, hay muchas esperanzas depositadas en este péptido como un agente antitumoral de amplia utilización. Por una parte presenta actividad antineoplásica en diversos modelos in vivo e in vitro en tumores para los cuales los tratamientos actuales no resultan eficaces (mama, próstata, páncreas, colon y pulmón) ${ }^{16}$. Por otro lado, su uso clínico en el tratamiento de la acromegalia y en el síndrome carcinoide ha permitido comprobar su buena tolerancia, si se compara con terapias antineoplásicas utilizadas habitual- 


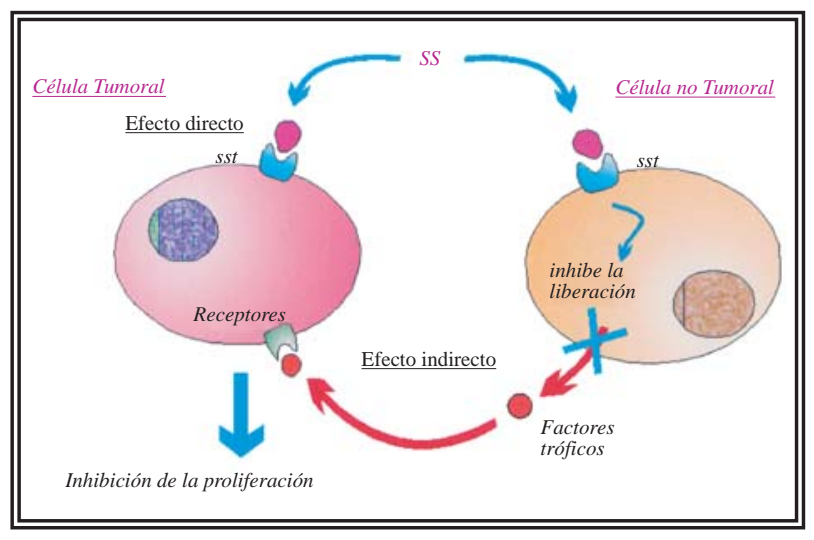

FIGURA 2. Acciones de la SS sobre tumores. La SS puede actuar directamente, a través de sus receptores, sobre la célula tumoral (izquierda) o indirectamente inhibiendo la liberación de factores tróficos por células no tumorales (derecha). En cualquier caso, el efecto final es inhibir la proliferación celular.

mente $^{21}$. Sin embargo, hasta el momento, los ensayos preclínicos y clínicos realizados con SS no han dado los resultados esperados, debido probablemente a que no se conoce con precisión cuales son los mecanismos moleculares implicados en su acción antiproliferativa ${ }^{22-24}$.

En los últimos años, resultados obtenidos por diferentes investigadores sugieren que el receptor sst2 podría ser el responsable del efecto antiproliferativo de la SS; de hecho, se ha constatado que la expresión de sst2 se pierde en el adenocarcinoma pancreático ${ }^{25,26}$ y en el carcinoma colon-rectal de alto grado ${ }^{25,27}$. Por lo tanto, su ausencia podría favorecer el crecimiento de estos tumores. Más aún, podría incluso explicar el fallo terapéutico que algunos ensayos clínicos preliminares con análogos de SS han documentado. En este sentido, se están realizando estudios de terapia génica con tumores pancreáticos carentes de sst2. La restauración de la expresión de este receptor ha permitido revertir la tumorigenicidad de células BxPC-3 y Capan-1 en estudios con xenógrafos ${ }^{28,29}$. Este efecto antineoplásico de la SS a través de sst2 parece estar mediado por la activación de una o varias fosfotirosinas fosfatasas ${ }^{19}$.

\section{PROTEÍNAS TIROSINAS FOSFATASAS}

Hace 40 años se reconoció, por primera vez, que la fosforilación reversible de proteínas es un proceso dinámico implicado en la regulación de múltiples funciones celulares. De las miles de proteínas que se expresan en una célula típica de mamífero, un tercio contiene un grupo fosfato unido covalentemente. Los tres aminoácidos que pueden ser fosforilados en las proteínas son: Ser, Thr y Tyr. La fosforilación en residuos Ser/Thr es mucho más frecuente que en residuos Tyr. Sin embargo, aunque estos últimos sólo representan el 0,01-0,05\% del total de fosfoaminoácidos, regulan procesos cruciales para el funcionamiento de la célula y de cualquier organismo como son el crecimiento, la diferenciación y la transformación celular ${ }^{30-32}$. Los niveles de fosforilación en tirosina son el resultado de la acción coordinada y regulada de dos tipos de enzimas: proteínas tirosinas quinasas (PTKs) y proteínas tirosinas fosfatasas (PTPs) ${ }^{33}$.

Inicialmente, la mayoría de los estudios se centraron sobre las PTKs, mientras que las PTPs no despertaron un interés especial en la comunidad científica. Se las consideraba un componente poco sofisticado en las reacciones de fosforilación, incluso se dudaba de su especificidad al pensar que sólo unas pocas tirosinas fosfatasas, relativamente inespecíficas, eran capaces de terminar el trabajo de numerosas tirosinas quinasas. Sin embargo, los resultados de los últimos años han demostrado que las PTPs forman una gran superfamilia de enzimas, sometidas a una compleja regulación, que van a intervenir en el control de múltiples rutas de señalización celu$\operatorname{lar}^{32}$. Además, presentan una elevada especificidad de sustrato, llegando incluso a diferenciar el lugar de fosforilación que será hidrolizado dentro de cada sustrato.

Actualmente, la superfamilia de las PTPs está formada por las denominadas PTPs clásicas, PTPs de especificidad dual y las PTEN (Phosphatase and Tensin homolog deleted on chromosome 10) (Fig. 3). Todas ellas, aunque tienen pocas homologías en su secuencia, utilizan el mismo mecanismo catalítico y presentan un centro activo con una estructura terciaria similar y la secuencia consenso HCxxGxxR.

Las PTP clásicas se caracterizan por tener al menos un dominio de 240-250 aminoácidos muy conservados que rodean a la secuencia consenso y que se denomina dominio catalítico o dominio PTP. Esta familia puede subdividirse en 2 sub- 


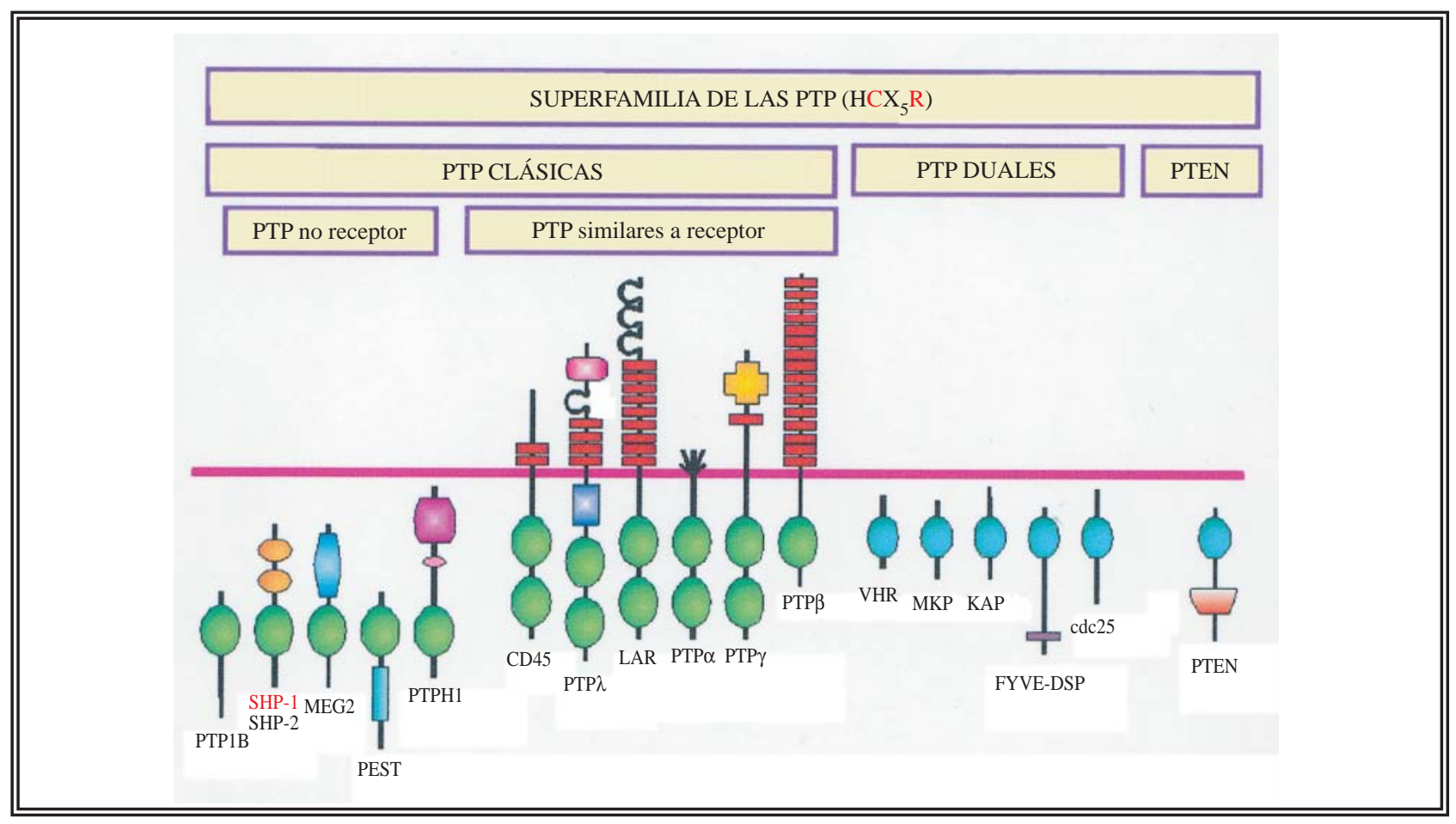

FIGURA 3. Superfamilia de las fosfotirosinas fosfatasas.

grupos, dependiendo de la localización celular: las PTPs no receptor o intracelulares y las PTPs transmembrana o similares a un receptor. Las PTP no receptor son enzimas intracelulares que tienen un solo dominio catalítico. En su extremo $\mathrm{N}$-terminal o C-terminal aparecen diferentes dominios estructurales de longitud variable y homólogos a los que aparecen en otras proteínas. Estos segmentos no catalíticos controlan la función de estas PTPs, dirigiéndolas a compartimentos subcelulares específicos o modulando directamente la actividad enzimática. Además, la actividad de la enzima se regula por cambios conformacionales causados por fosforilación en residuos de Ser/Thr o Tyr, o a través de la interacción del dominio catalítico con los propios dominios no catalíticos adquiriendo una conformación inactiva, como ocurre en las SHP-1 y SHP- $2^{32}$. Las PTP transmembrana presentan una estructura similar a la de un receptor típico de membrana: un dominio extracelular variable, un dominio transmembrana y uno o dos dominios catalíticos intracelulares. Los dominios extracelulares pueden interaccionar con ligandos que regulan la actividad de los dominios catalíticos. Estos dominios presentan una gran variabilidad estructural, posiblemente reflejo de sus diferentes funciones y ligandos fisiológicos. En la mayoría de los casos, en estos dominios aparecen secuencias similares a las presentes en proteínas implicadas en procesos de adhesión celular, lo que sugiere que estas PTPs pueden participar activamente en los procesos de interacción célula-célula y célula-matriz extracelular ${ }^{31}$. Las fosfatasas de especificidad dual (DSP) poseen capacidad de desfosforilar residuos de pSer/pThr y pTyr. Al igual que otras fosfatasas, muestran una alta selectividad de sustratos regulando vías de señalización celular importantes como la de MAPK $^{34}$.

La PTEN se identificó inicialmente como un gen supresor de tumores localizado en el cromosoma 10q23, región que está alterada en el 70\% de los glioblastomas y en el $60 \%$ de los cánceres de próstata avanzados. La proteína que codifica este gen es similar a las PTPs de especificidad dual, pero además de desfosforilar residuos de pTyr, desfosforila fosfatidilinositol-3,4,5-trifosfato $\left(\mathrm{PIP}_{3}\right)$. Este lípido es un componente clave en la activación de la Ser/Thr quinasa Akt, una de las principales rutas de control del crecimiento celular. La pérdida de la PTEN, durante la tumorogé- 
nesis, mantendría la Akt permanentemente activa, permitiendo a las células proliferar sin control $^{35}$. Existen clasificaciones anteriores en las que se incluía a esta PTP junto con las de especificidad dual. Actualmente se separa este grupo de enzimas porque poseen especificidad por sustratos de diferente naturaleza: lípidos y proteínas fosforiladas en Tyr. Otro miembro de este grupo es la miotubularina (MTM) ${ }^{36}$.

\section{SHP-1}

En 1986, Sadowski y cols. ${ }^{37}$ identificaron un dominio N-terminal que estaba altamente conservado entre las proteínas tirosinas quinasas citoplasmáticas de la familia Src. A este dominio Nterminal, de aproximadamente 100 aminoácidos, lo denominaron SH2 (dominio 2 de homología con Src). Años después, se descubrió la presencia de dominios SH2 en proteínas que intervienen en la transducción de señales como la fosfolipasa $\mathrm{C} \gamma 1$, la proteína estimuladora de la actividad GTPasa (GAP), la fosfatidil inositol 3 quinasa (PI3K) y la proteína de unión a actina (tensina).

Los dominios SH2 unen específicamente residuos tirosina fosforilados, y la secuencia adyacente a este residuo es la que determina la especificidad de unión. Por lo tanto, estos dominios juegan un papel importante en las interacciones entre los receptores tirosina quinasa para los factores de crecimiento y las proteínas implicadas en la transducción de señales. Los receptores para factores de crecimiento son activados tras la unión de sus ligandos, dando lugar a una autofosforilación en múltiples residuos tirosina situados en su domino intracelular, creando sitios de unión específicos para proteínas citoplasmáticas con dominios SH2. Estas proteínas, como resultado de esa unión, pueden ver modificada su actividad y su especificidad de sustrato.

Hasta el momento se conocen tres PTPs con dominios SH2: SHP-1 (anteriormente llamada PTP1C) ${ }^{38}$, SH-PTP1 ${ }^{39}$, Hcp o SHP ${ }^{40}$ presente en mamíferos, SHP-2 (anteriormente llamada PTP1D ${ }^{41}$, PTP2C $^{42}$, SH-PTP2 ${ }^{43}$, Syp $^{44}$, SH-PTP3 ${ }^{45}$, o (SAP-2 ${ }^{46}$ también presente en mamíferos, y Corkscrew o csw en Drosophila. La SHP-1 se expresa principalmente en células hematopoyéticas y epiteliales, mientras que la SHP-2 y la csw son más ubicuas. La estructura de todas ellas es muy similar (Fig. 4). Poseen dos dominios SH2 ubicados en el extremo N-terminal, un dominio catalítico y en el extremo C-terminal dos sitios de fosforilación en Tyr que le permiten interaccionar con otras proteínas con dominios $\mathrm{SH} 2^{47}$.

La SHP-1 es una enzima citosólica de aproximadamente $66 \mathrm{kDa}$ que se expresa preferentemente en células hematopoyéticas, aunque existe una variante en algunos tipos de células epiteliales $^{48}$. La existencia de dos cepas de ratones (motheaten (me) y motheaten viable $\left.\left(m e^{v}\right)\right)^{49}$ que carecen de SHP-1 o expresan una forma deficiente de la enzima con sólo un 20\% de actividad, han permitido demostrar que esta PTP es un regulador negativo de múltiples señales en células hematopoyéticas, entre las que se incluyen las activadas por interleuquinas, factores de crecimiento, adhesión e inmunoreceptores ${ }^{50}$.

En células no-hematopoyéticas, SHP-1 actúa regulando procesos activados por factores de crecimiento, neuropéptidos y citoquinas. La activación de receptores tirosina quinasas (EGF, PDGF, IGF-1) o de receptores que activan tirosina quinasas tipo no-receptor (Src, Jak, Syk) producen la fosforilación de un gran número de sustratos, activando sistemas de señalización intracelular que regulan el crecimiento celular, la diferenciación, la migración y la apoptosis ${ }^{51}$. Las tirosinas fosfatasas cumplen un papel decisivo desactivando muchas de estas señales. Diversos estudios demuestran que SHP-1 es capaz de unirse al receptor del EGF fosforilado e inactivarlo ${ }^{38,52,53}$. Este efecto es específico de

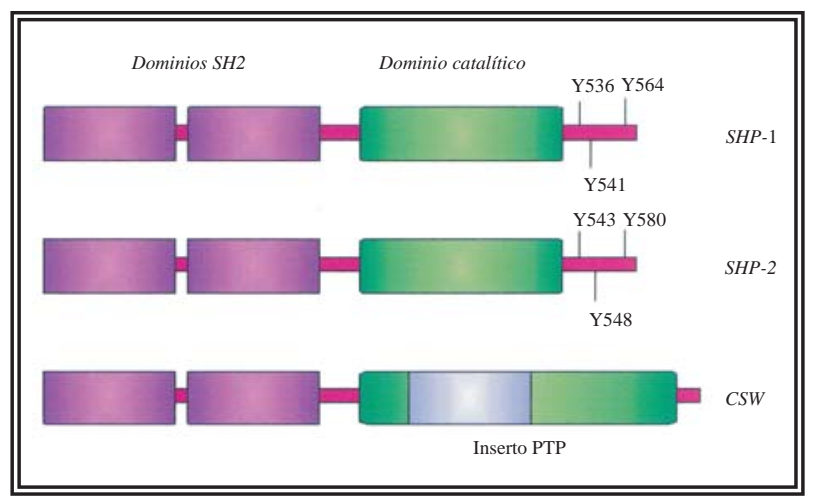

FIGURA 4. Estructura de las PTPs con dominios SH2. Las tres PTPs de este grupo poseen dos dominios SH2 ubicados en el extremo $N$-terminal, un dominio catalitico en el extremo C-terminal y dos sitios de fosforilación en Tyr. 
SHP-1 porque al utilizar quimeras SHP-1/SHP2 , con el dominio catalítico de SHP-2, no se produce esta inactivación ${ }^{53}$. El mismo resultado se ha observado con HER, perteneciente a la misma familia de receptores tirosina quinasas $^{41}$. También se ha visto que la SHP-1 está implicada en la regulación de las señales activadas por $\mathrm{NGF}^{54}$, por insulina ${ }^{55}$ y por el factor de crecimiento de hepatocitos ${ }^{56}$.

En cuanto a las citoquinas, SHP-1 regula las señales activadas por IL- ${ }^{57}$, por eritropoyetina ${ }^{58}$ y por INF- $\alpha^{59}$. En muchos de estos casos el mecanismo de acción podría consistir en la regulación de quinasas de la familia Janus (Jak1 y Jak3), ya sea desfosforilando al receptor y/o a las propias Jak quinasas ${ }^{60}$. Particularmente, interesantes son los hallazgos que involucran a la SHP-1 en el papel antiproliferativo de algunos péptidos como la angiotensina $\mathrm{II}^{61}$ y la somatostatina ${ }^{62,63}$. Sin embargo, no en todos los casos SHP-1 cumple un papel inhibidor. Su y colaboradores ${ }^{64}$, describieron que la sobre-expresión de SHP-1 catalíticamente inactiva, en células 293 (células provenientes de riñón de embriones), inhibe las señales mitogénicas inducidas por el EGF y el suero, disminuyendo marcadamente la fosforilación de proteínas que integran la vía de las MAPK. Al añadir la SHP-1 normal, se revierte este efecto indicando que esta enzima podría cumplir un papel estimulador en estas células.

\section{SHP-1, SOMATOSTATINA Y PROLIFERACIÓN CELULAR}

Como ya hemos mencionado la activación de PTPs está relacionada con las propiedades antiproliferativas de la SS. Muchos estudios se han centrado en este sistema de señalización, a través del cual la SS podría atenuar las señales desencadenadas por factores de crecimiento y por otros mitógenos. Sin embargo, los resultados obtenidos hasta el momento no son concluyentes. Aunque se haya podido demostrar la participación de una actividad fosfotirosina fosfatasa en este efecto antiproliferativo, no en todos los casos se ha identificado la enzima responsable de esa actividad ni el subtipo o subtipos de receptores de SS asociados ${ }^{25,66,67}$. Sin embargo, resultados obtenidos por diferentes investigadores en los últimos años sugieren que sería la SHP-1 la enzima responsable del efecto antiproliferativo de la SS, en la mayoría de los casos a través del receptor sst2.

La SHP-1 inmunoprecipita con sst2 y Gi 3 , lo que demuestra que están constitutivamente asociadas $^{68}$. De hecho, la SS y sus análogos inducen la disociación de SHP-1, su fosforilación y su activación $^{62}$ (Fig. 4). Una vez activada SHP-1 puede desfosforilar e inactivar sustratos que estimulan la proliferación celular. En este sentido, Bousquet y cols. ${ }^{69}$ demuestran que la SS acelera y amplifica los efectos de SHP-1 sobre la ruta de transducción de señales de la insulina, inhibiendo sus efectos mitogénicos. Concretamente SS, a través de SHP-1, desfosforila e inactiva el receptor de insulina y sus sustratos: IRS-1 y Shc.

En 1996, Rauly y cols. ${ }^{70}$ crearon un modelo con células NH3T3 transfectadas con el receptor sst2 y observaron que la expresión de este receptor inducía la aparición de un bucle autocrino que involucraba también a la SHP-1, y que provocaba la inhibición de la proliferación celular. Hallazgos más recientes en ratones que expresan SHP-1 catalíticamente inactiva demuestran que la SS, a través de sst2 y SHP-1, induce parada del ciclo celular en $G_{1}$ por aumento de los niveles de p2 $7^{\text {Kip } 1}$ (inhibidor de la ciclina quinasa) ${ }^{71,72}$. En este sentido, estudios en células FTRL-5, derivadas de células foliculares tiroideas, han revelado que la SS inhibe los efectos proliferativos de la TSH restableciendo los niveles de p27 Kip1(73,74).

Además de los mecanismos citostáticos observados, parece evidente que la activación de SHP1 induce también apoptosis. La translocación de SHP-1 a la membrana es un fenómeno temprano y esencial en la acidificación y en la apoptosis inducida por la SS ${ }^{75}$ (Fig. 5). Estos efectos parecen estar inducidos vía sst3 y proteínas $\mathrm{Gi}$, al bloquearse por la toxina pertussis (PTX), y se acompañan tanto de un aumento de p53 como de la proteína proapoptótica $\mathrm{Bax}^{76}$. Estudios posteriores confirman la activación de endonucleasas ácidas insensibles a cationes ${ }^{77}$ y de la caspasa$8^{87}$. SHP- 1 induce un descenso del $\mathrm{pH}$ intracelular mediante la inhibición del intercambiador $\mathrm{Na}^{+} / \mathrm{H}^{+}(\mathrm{NHE})$ y la bomba $\mathrm{H}^{+}-\mathrm{ATPasa}^{79-81}$. Al contrario de lo que ocurre con sst3, los otros subtipos de receptores no inducen apoptosis, sino parada del ciclo en $\mathrm{G}_{1}$ mediante el aumento de $\mathrm{Rb}$ 


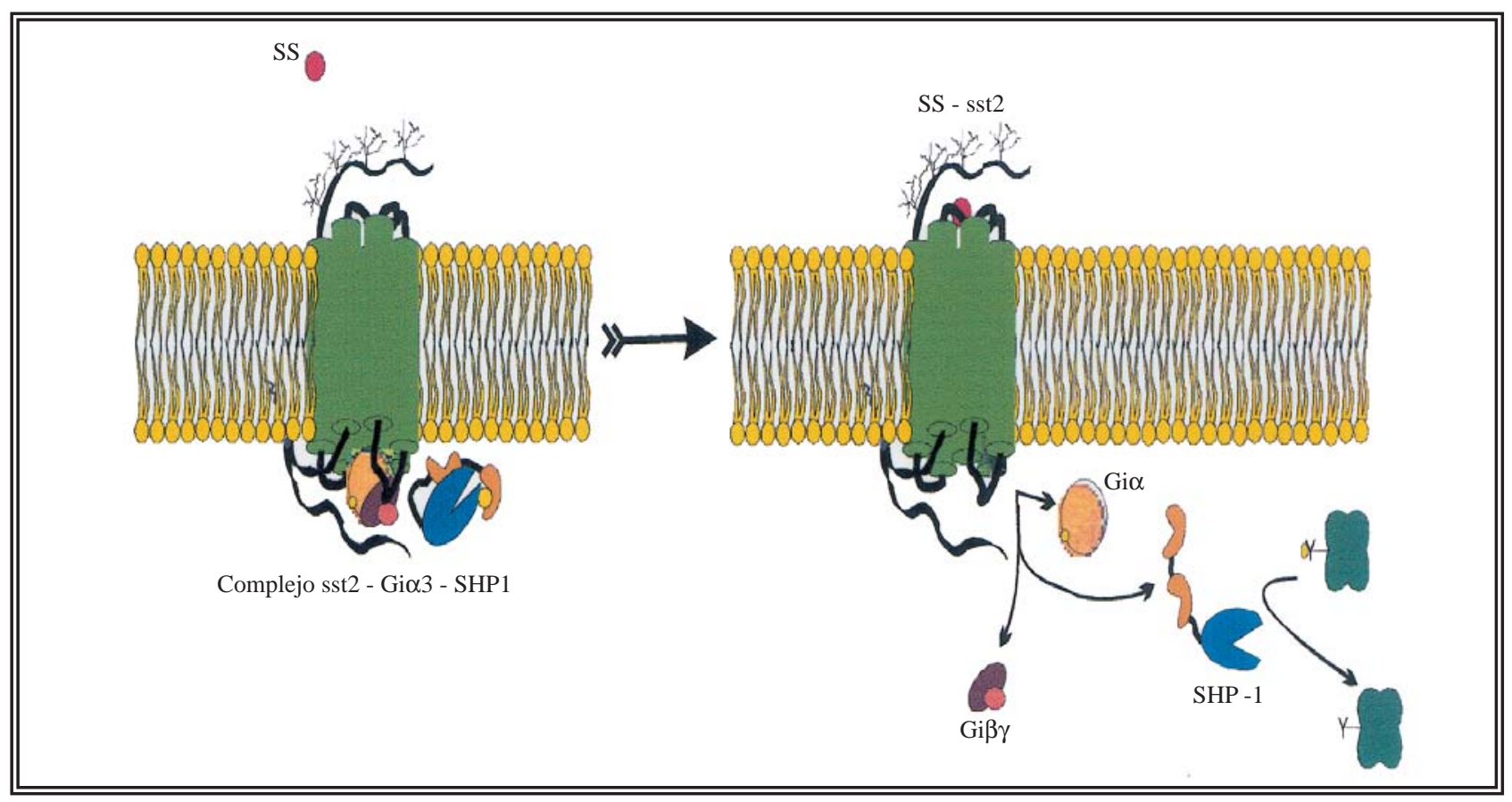

FIGURA 5. Modelo de activación de SHP-1 por SS. En el estado basal la SHP-1 se encuentra inactiva y formando un complejo con el receptor Sst2 y Gia3. La unión de la SS a su receptor induce la disociación y la activación de SHP-1 que puede unirse, a través de sus dominios $\mathrm{SH} 2$, a otras proteinas regulando su actividad mediante defosforilación.

y p21 $1^{\text {Cip1,66 }}$. La presencia de residuos específicos del segmento C-terminal parecen ser críticos a la hora de desencadenar esta señal, probablemente a través de la internalización del receptor y de la activación de MAPK. No obstante, se necesitan más estudios para interpretar con propiedad las funciones que cumplen las PTPs en cada tipo celular, y en cada órgano o tejido. En este sentido, sería importante encontrar sistemas que expresen de forma natural, tanto los receptores como sus sistemas de señalización, porque las observaciones procedentes de células transfectadas pueden estar de algún modo enmascaradas o ser, cuando menos, forzadas.

\section{SS Y CÁNCER DE PRÓSTATA}

Desde un punto de vista histórico existen datos sobre la acción antiproliferativa de la SS en la próstata sólo desde la década de los ochenta. Inicialmente se pensó que este efecto sería indirecto dada la capacidad de la SS para inhibir la liberación de GH y de prolactina. Sin embargo, Di Sant'Agnese, en $1984^{82}$, describe por primera vez en próstata humana la presencia de células endocrina-paracrinas que secretan somatostatina.
Los estudios realizados hasta el momento demuestran que diferentes análogos de la SS son capaces de reducir el tamaño y el volumen de tumores prostáticos inducidos en ratones. En xenógrafos inoculados con células PC3, Pinski y cols. ${ }^{83}$ encontraron que el RC-160 era capaz de reducir el tamaño y el volumen de tumores prostáticos, siempre que el tratamiento comenzara en estadios tempranos del tumor. Este análogo producía una disminución de los niveles de GH, IGFI y EGFR.

Sin embargo, los escasos datos clínicos que existen acerca de la utilización de la SS en el carcinoma prostático son contradictorios, dado que ensayos clínicos realizados por diferentes equipos arrojan resultados opuestos. Verhelst y cols. ${ }^{84}$ administraron SMS 201-995, sólo o combinado con análogos de LHRH, a pacientes que padecían carcinoma de próstata metastático y observaron inhibición moderada y temporal del crecimiento del tumor. Por el contrario, Logothetis y cols. ${ }^{24}$ utilizaron el mismo análogo con un grupo de 24 pacientes que padecían cáncer de próstata avanzado y refractario al tratamiento hormonal, obteniendo resultados desalentadores. El SMS 201995, después de dos meses de tratamiento, ace- 
leró el crecimiento del tumor y produjo un rápido aumento del PSA apareciendo nuevas metástasis óseas y viscerales. Maulard y cols. ${ }^{23}$ analizaron el efecto del tratamiento con lanreotide (BIM 32014) sobre pacientes con cáncer prostático resistente a hormonas, observando cierta mejoría en el estado general y disminución o estabilización de los niveles de PSA. Por otro lado, Figg y cols. ${ }^{22}$ no encontraron ninguna mejora clínica al tratar pacientes con cáncer de próstata metastásico con dosis crecientes de somatulina (SMS 201-995). Vainas y cols. ${ }^{85}$ realizaron ensayos clínicos de fase II, administrando SMS 201-995 a pacientes con bloqueo androgénico total, encontrando que el tratamiento mejora el estado general y prolonga la fase libre de síntomas. Recientemente, Berruti y cols. ${ }^{86}$ han encontrado efectos positivos del lanreotide administrado a pacientes en fase independiente de andrógenos. $\mathrm{El}$ análogo produjo una disminución de los niveles plasmáticos de cromogranina A e IGF-I, sin observarse cambios en los niveles de PSA. La razón de estas discrepancias $\mathrm{y}$, en muchos casos, del escaso efecto terapéutico puede deberse a modalidades de aplicación inadecuadas (dosis, régimen, tipo de análogos utilizados), a la diferente eficacia de la SS dependiendo de los sitios de actuación (sistema endocrino, inmune, neurovascular y el propio tumor) o al desconocimiento de los subtipos de receptores para SS y de los diferentes sistemas de transducción de señales utilizados que, en último caso, determinarán las funciones celulares que van a ser modificadas.

Diversos grupos de investigación han demostrado la presencia de receptores de SS en células prostáticas normales y tumorales. Reubi y cols. ${ }^{87}$ mediante hibridación in situ combinada con técnicas autoradiográficas, demostraron la presencia de sst2 en próstata normal y de sst1 en cáncer de próstata. En ambos casos los receptores estaban localizados exclusivamente en células estromales. Posteriormente, Sinisi y cols. en $1997^{88}$, mediante RT-PCR realizada con RNA procedente de células epiteliales y estromales cultivadas, demuestran que sólo aparecen receptores para somatostatina en las células epiteliales. Así, mientras que las células procedentes de próstata normal expresan sst2, sst4 y sst5, las procedentes de cáncer de próstata expresan sst1, sst4 y sst5. Halmos y cols. ${ }^{89}$ encontraron sst1, sst2 y sst5 en 80 muestras de prostatectomía radical analizadas por RT-PCR. Desde un punto de vista cuantitativo la expresión del receptor sst2 fue minoritaria (14\%), mientras que sst5 y sst1 aparecieron de forma dominante ( $64 \%$ y $86 \%$, respectivamente) lo que parecía demostrar que en el cáncer de próstata, al igual que en otros tipos de tumores, se perdía sst2, aunque los propios autores comprueban que la expresión de los receptores para SS no se ve afectada por la progresión del tumor. Recientemente, nuestro grupo de investigación ha demostrado que las líneas tumorales prostáticas humanas PC3 y LNCaP expresan sst2 y sst5; pero además de tener los citados receptores estas células producen y secretan SS. La expresión conjunta por la misma célula del péptido y de sus correspondientes receptores generaba un bucle autocrino que demostró ser funcional, regulando de forma negativa la proliferación celular63.

Por lo tanto, aunque se ha demostrado claramente la presencia de receptores para somatostatina en células prostáticas normales o tumorales, los resultados obtenidos sobre su localización, los subtipos que se expresan y su relación con diferentes situaciones fisiopatológicas no son concluyentes.

Son muchas las preguntas sin respuestas respecto a la implicación de la SS en la fisiopatología prostática. Creemos que para poder dilucidar todos estos interrogantes resulta imprescindible conocer los receptores que expresa la próstata normal y el cáncer de próstata, cual de estos es responsable del efecto antiproliferativo, y el mecanismo o mecanismos empleados; así como la contribución relativa de sus efectos directos e indirectos sobre el control de la proliferación celular de la próstata y en la diferenciación neuroendocrina prostática.

\section{SHP-1 Y CÁNCER DE PRÓSTATA}

A pesar de la gran cantidad de estudios que existen sobre los efectos de la SS y de sus análogos en el cáncer de próstata, la mayoría de éstos se centran en investigar la presencia o ausencia de los diversos receptores, y en la realización de ensayos clínicos para evaluar el potencial valor 
terapéutico de este péptido. Nuestro grupo es uno de los pioneros en dilucidar los mecanismos moleculares utilizados por la SS para regular el crecimiento de la próstata. Creemos que estudios de este tipo son de suma importancia, dado que la presencia de los receptores no garantiza que el péptido pueda realizar sus efectos. De hecho, debemos ser conscientes que la presencia de un/os receptor/es no garantiza necesariamente su funcionamiento ni su empleo terapéutico. Sabemos que en ocasiones se produce un desequilibrio entre los receptores y los mecanismos intracelulares que haría ineficaz la utilización de análogos de SS, o incluso que podría producir resultados adversos.

En 1993, Brevini y cols. ${ }^{90}$ sugirieron que la somatostatina era capaz de inhibir directamente la secreción y la proliferación de células LNCaP. El mecanismo de este efecto parecía estar mediado por la activación de una fosfotirosina fosfatasa no identificada. Recientemente nuestro grupo de investigación ha demostrado de forma original la presencia de SHP-1 en próstata ventral de $\operatorname{rata}^{91} \mathrm{y}$ en próstata humana ${ }^{63,92}$.

SHP-1 también se ha encontrado en las líneas tumorales prostáticas humanas $\mathrm{PC} 3$ y $\mathrm{LNCaP}^{93}$. Las observaciones indican que la SS, producida endógenamente por estas líneas celulares, aumenta la cantidad y la actividad de SHP-1; de hecho, el bloqueo de este péptido aumenta la proliferación celular coincidiendo con una disminución de la actividad y la cantidad de SHP-1. Por lo tanto, la SHP-1 es un componente más del bucle autocrino para SS detectado en estas líneas celulares, capaz de inhibir la proliferación celular. Sin embargo, estas líneas celulares expresan otras PTPs como la SHP-2 y la PTP1 B ${ }^{94}$ (Fig. 6), que también podrían participar en el control de la proliferación celular como sugieren algunos autores ${ }^{95}$.

La SHP-1 se localiza en las células epiteliales ductales y acinares de la próstata humana y de la próstata ventral de rata ${ }^{63,94}$. Tanto en la próstata de la rata como en la humana, la ubicación de la enzima se restringe a la zona apical de las células epiteliales ductales, mientras que en las células acinares la distribución es menos restrictiva. Es probable que la distribución de esta enzima coincida con la localización de receptores o moléculas

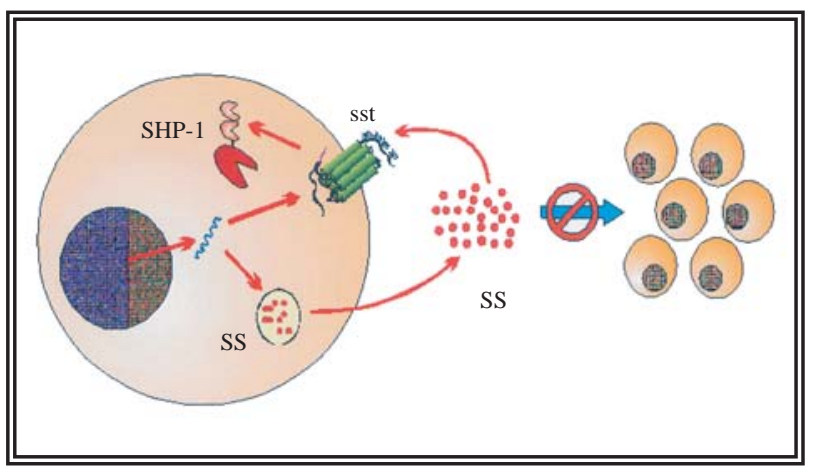

FIGURA 6. Bucle autocrino antiproliferativo. La SS secretada por la célula epitelial prostática actúa de forma autocrina sobre receptores sst2 y sst5, presentes en las mismas células, $e$ inhibe la proliferación celular mediante la activación de la fosfotirosina fosfatasa SHP-1.

con las que SHP-1 va a interaccionar, por lo que para dilucidar su significado será necesario conocer con detalle los procesos celulares en los que está involucrada. En cualquier caso, las células epiteliales prostáticas pasan a integrar la limitada lista de células no hematopoyéticas que expresan SHP- 1.

Asímismo, se ha realizado un estudio en tumores prostáticos humanos de la expresión y localización de SHP-1, dependiendo del grado de diferenciación del tumor (Tabla II). Nuestros hallazgos indican que la enzima está presente en alteraciones no malignas, así como en adenocarcinomas en estadios tempranos; pero que desaparece a medida que el tumor es más indiferenciado. Es decir, tumores con patrón de Gleason más alto muestran menos expresión de SHP-1 que tumores con bajo Gleason ${ }^{63}$ (Fig. 7). Estos resultados están en el mismo sentido que los obtenidos en las líneas celulares: la cantidad de SHP- 1 expresada en LNCaP es mayor que en PC3. Las células LNCaP que representan una fase temprana del cáncer de próstata y son más diferenciadas, tienen más SHP-1 que las PC3. Además, cuando las células PC3 se inyectan en ratones atímicos demuestran una agresividad e invasividad superior a las $\mathrm{LNCaP}$ al formar tumores más indiferenciados. Por lo tanto, la pérdida de expresión de SHP-1 puede relacionarse estrechamente con el desarrollo y la progresión del cáncer de próstata. En otros tipos de tumores también se ha detectado baja expresión de SHP-1; entre otros en adenocarcinomas pancreáticos ${ }^{96}$, linfomas ${ }^{97-99}$ y 
TABLA II

DISTRIBUCIÓN INMUNOHISTOQUÍMICA DE SHP-1 EN PRÓSTATA NORMAL Y PATOLÓGICA

\begin{tabular}{|c|c|c|c|}
\hline Muestra & Inmunotinción SHP-1 & Localización & Patrón \\
\hline $\begin{array}{l}\text { Próstata normal } \\
\text { Ductos } \\
\text { Glándulas }\end{array}$ & $\begin{array}{l}+ \\
+\end{array}$ & $\begin{array}{l}\text { Citoplasmática apical } \\
\text { Citoplasmática difusa }\end{array}$ & $\begin{array}{l}\text { granular } \\
\text { no granular }\end{array}$ \\
\hline $\begin{array}{l}\text { Próstata hiperplásica } \\
\text { Glándulas hiperplásicas } \\
\text { Glándulas atróficas } \\
\text { Hiperplasia de células basales } \\
\text { Metaplasia transicional en ductos }\end{array}$ & $\begin{array}{c}+ \\
+ \\
+ \\
++\end{array}$ & $\begin{array}{l}\text { Citoplasmática apical } \\
\text { Citoplasmática difusa } \\
\text { Citoplasmática difusa } \\
\text { Citoplasmática difusa }\end{array}$ & $\begin{array}{l}\text { granular } \\
\text { no granular } \\
\text { no granular } \\
\text { no granular }\end{array}$ \\
\hline $\begin{array}{l}\text { PIN } \\
\text { PIN alto grado }\end{array}$ & + & Citoplasmática difusa & no granular \\
\hline $\begin{array}{l}\text { Adenocarcinoma } \\
\text { Bien diferenciado } \\
\text { Poco diferenciado } \\
\text { Ductal }\end{array}$ & $\begin{array}{l}+ \\
- \\
+\end{array}$ & $\begin{array}{c}\text { Citoplasmática difusa } \\
- \\
\text { Citoplasmática difusa }\end{array}$ & $\begin{array}{c}\text { no granular } \\
- \\
\text { no granular }\end{array}$ \\
\hline
\end{tabular}

-: Negativo +: Positivo ++: Altamente positivo

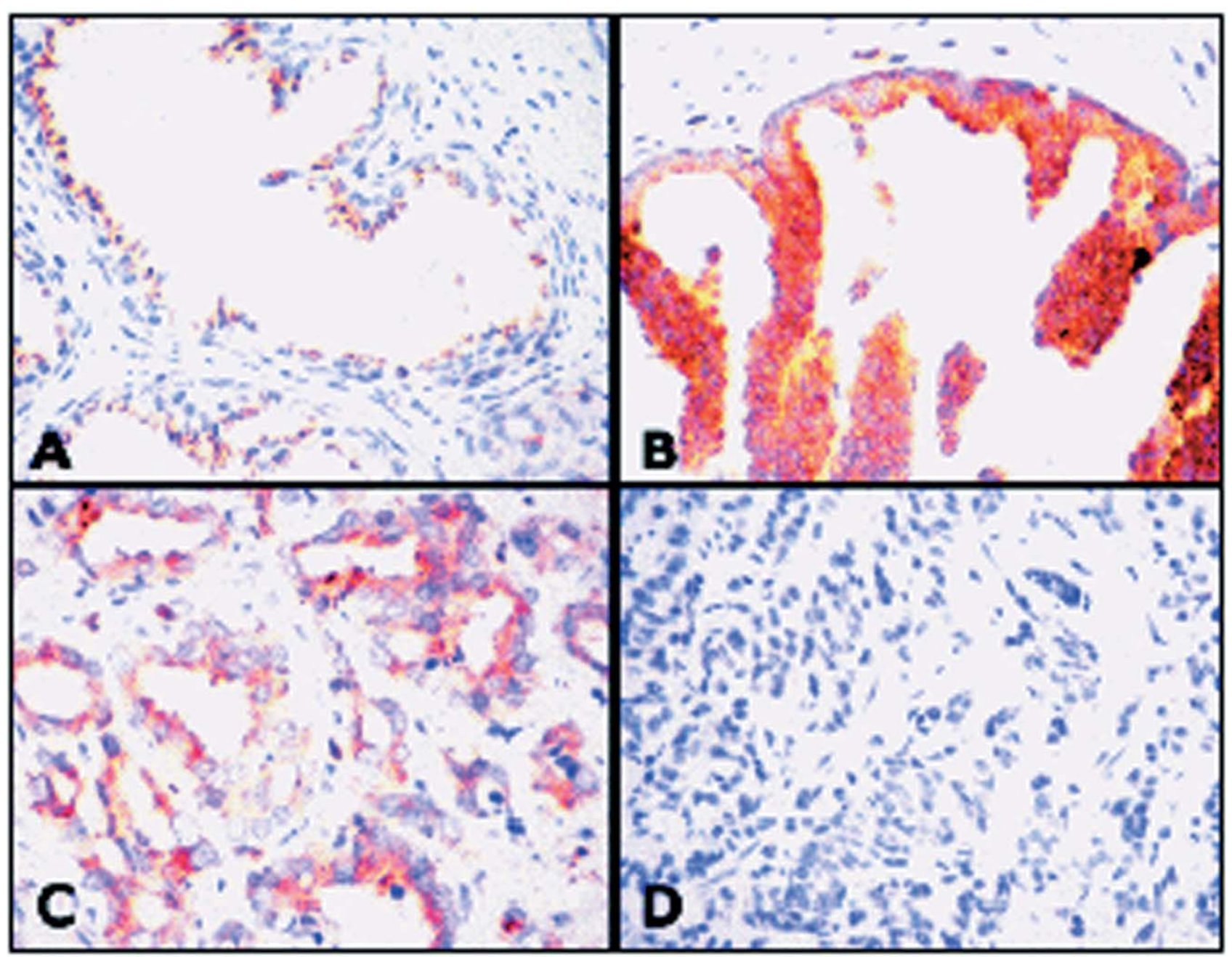

FIGURA 7. Distribución de SHP-1 en la próstata humana. Inmunotinción positiva para SHP-1 en hiperplasia prostática benigna (A), PIN de alto grado (B) y adenocarcinoma bien diferenciado (C). Tinción negativa para SHP-1 en adenocarcinoma poco diferenciado (D). 
policitemia vera ${ }^{100}$. En algunos estudios la pérdida de SHP-1 se asocia a mayor sensibilidad a los efectos mitogénicos de los factores de crecimiento.

Como ya hemos mencionado, los factores de crecimiento están directamente implicados en el control del crecimiento de la próstata. Una de las alteraciones más frecuentes durante el desarrollo del carcinoma de próstata, es la aparición de bucles autocrinos para factores de crecimiento, lo que sin duda representa una adaptación a la deprivación androgénica. Esta deprivación también podría generar un bucle autocrino para la $\mathrm{SS}$, que sería incapaz de inhibir la proliferación celular en ausencia de SHP-1. Recientemente, Halmos y cols. ${ }^{89}$ han demostrado que la expresión de los receptores para SS no se ve afectada por la progresión del tumor. Por lo tanto, alteraciones post-receptor, como la pérdida de la SHP1, podrían implicarse en la progresión del cáncer de próstata al permitir que persistan las señales generadas por los factores de crecimiento. En este sentido Douziech y cols. ${ }^{96}$ demuestran que la SS tiene efectos opuestos sobre la proliferación de células derivadas de cáncer de páncreas, dependiendo de la presencia o no de SHP-1. En ausencia de esta PTP, la SS no inhibe la proliferación celular.

La distribución difusa de SHP-1 en tumores bien diferenciados puede indicar pérdida de la polaridad celular y alteraciones iniciales de los mecanismos en los que se involucra esta enzima. Por otro lado, la pérdida de expresión de SHP-1 en fases avanzadas de la enfermedad, junto con el conocimiento de la relación que existe entre SHP1 y SS, y la observación clínica de que la enfermedad neoplásica prostática hormonorresistente se relaciona con fenómenos neuroendocrinos locales poco conocidos a día de hoy, nos llevan a considerar que la proteína fosfotirosina fosfatasa objeto de esta revisión (SHP1) está definitivamente implicada en la progresión del cáncer de próstata. En este momento estamos estudiando un mayor número de muestras humanas, con intención de aclarar su papel en la patología humana y comprender mejor el significado de los patrones de distribución que preceden a su pérdida total.

El conjunto de todos los resultados comentados demuestran que los efectos antiproliferativos de la SS sobre la próstata están, al menos en parte, mediados por la fosfotirosina fosfatasa SHP-1, presente en estas células y activada a corto y largo plazo por la SS. Esta enzima también está presente en muestras de próstata humana con hiperplasia prostática benigna y con cáncer bien diferenciado. Ahora bien, está ausente en cáncer de próstata avanzado poco diferenciado. Pensamos que SHP-1 juega un papel clave en el control de la proliferación celular prostática y su presencia determinará el potencial terapéutico de la SS en el control del cáncer de próstata.

\section{INVESTIGACIONES DE FUTURO}

Estos resultados abren a su vez la puerta a nuevas investigaciones. Se necesita estudiar mejor si la expresión de SHP-1 puede utilizarse como marcador de pronóstico o para clasificar los tumores, tal y como sucede en el caso de los linfomas de células B pequeñas ${ }^{97}$. Un estudio paralelo de la expresión de SS y de sus receptores proporcionará una visión global de todos los elementos del bucle autocrino que hemos descubierto, $\mathrm{y}$ la participación del mismo en el cáncer de próstata. Es posible que el patrón de expresión de receptores para SS en líneas celulares prostáticas humanas no sea representativo del que se encuentra in vivo. En cualquier caso, estas líneas celulares son útiles a la hora de analizar los efectos de pérdida o ganancia de un determinado tipo de receptor de SS o de SHP-1 sobre el fenotipo celular. Recientemente se han publicado estudios de terapia génica con tumores pancreáticos que carecen de sst2. La restauración de la expresión de este receptor induce un bucle autocrino para la SS mediado por SHP-1, a través del cual se modula la proliferación, adherencia e invasión celular $^{28,101}$.

Es posible que un mejor conocimiento de los mecanismos moleculares implicados en el efecto antiproliferativo de la SS permita explicar los resultados contradictorios de los ensayos clínicos realizados hasta el momento o que, por lo menos, permita una mejor planificación de futuros estudios. El desarrollo de nuevas terapias, o de terapias combinadas, para el carcinoma avanzado que no responde a la deprivación androgénica es uno de los principales retos que tiene hoy la oncología urológica. 
Agradecimientos: A la Fundación para la Investigación en Urología por las diversas becas concedidas, becas que han hecho posible la consolidación de este grupo y la financiación de sus aportaciones a la literatura.

\section{REFERENCIAS}

1. DENIS LJ.: Maximal androgen blockade: facts and fallacies. Endocr Rel Cancer 1998; 5: 353-356.

2. GRIFFITHS K.: Molecular control of prostate growth. In textbook of benign prostatic hyperplasia, 1 edn. Edited by Kirby R, Mc Connell JD, Fitzpatrick JM, Roehrborn CG, Boyle P. Oxford (UK): Isis Medical Media 1996: 23-55.

3. RUIJTER E, VAN DE KAA C, MILLER G, RUITER D, DEBRUYNE F, SCHALKEN J.: Molecular genetics and epidemiology of prostate cancer. Endoc Rev 1999; 20: 22-45.

4. RUSSELL DW, WILSON JD.: Steroid $5 \alpha$ reductase: two genes/two enzymes. Rew Biochem 1994; 63: 25.

5. JENSTER G.: The role of the androgen receptor in the development and progression of prostate cancer. Semin Oncol 1999; 26: 407-421.

6. BERTHON P, WALLER AS, VILLETTE JM.: Androgen are not a direct requirement for the proliferation of human prostatic epithelium in vitro. Int $J$ Cancer 1997; 73: 910-916.

7. BYRNE RL, LEUNG H, NEAL DE.: Peptide growth factors in the prostate as mediators of stromal epithelial interactions. Br J Urol 1996; 77: 627-633.

8. RUSSELL P, BENNETT S, STRICKER P.: Growth factor involvement in progression of prostate cancer. Clin Chem 1998; 44: 705-723.

9. DJAKIEW D.: Dysregulated expression of growth factors and their receptors in the development of prostate cancer. Prostate 2000; 42: 150-160.

10. ABRAHAMSSON PA.: Neuroendocrine differentiation in prostatic carcinoma. Prostate 1999; 39: 135-148.

11. APRIKIAN A, HAN K, GUY L, LANDRY F, BEGIN L, CHEVALIER S.: Neuroendocrine differentiation and the bombesin/gastrin-releasing peptide family of neuropeptides in the progression of human prostate cancer. Prostate Suppl 1998; 8: 52-61.

12. JIBORN T, BJARTELL A, ABRAHAMSSON PA.: Neuroendocrine differentiation in prostatic carcinoma during hormonal treatment. Urology 1998; 51: 585-589.

13. BONKHOFF H.: Neuroendocrine cells in benign and malignant prostate tissue: morphogenesis, proliferation, and androgen receptor status. Prostate 1998; 8: 18-22.

14. DI SANT'AGNESE PA.: Neuroendocrine differentiation in prostatic carcinoma. Hum Pathol 1992; 23: 287-296.

15. PATEL YC.: General aspects of the biology and function of somatostatin. In Basic and clinicla aspects of neuroscience, 1992 edn. Edited by Weil C, Muller EE, Thorner MO. Berlin: Springer-Verlag 1992: 1-16.

16. POLLAK MN, SCHALLY AV.: Mechanisms of antineoplastic action somatostatin analogs. Proc Soc Exp Biol Med 1998; 217: 1431-1452.
17. LAMBERTS SWJ, KRENNING EP, REUBI JC.: The role of somatostatin and its analogs in the diagnosis and treatment of tumors. Endocrine Rev 1991; 12: $450-482$.

18. YAMADA Y, POST SR, WANG K et al.: Cloning and functional characterization of a family of human and mouse somatostatin receptors expressed in brain, gastrointestinal tract, and kidney. Proc Natl Acad Sci USA 1992; 89: 251-255.

19. PATEL YC.: Somatostatin and its receptor family. Front Neuroendocrinol 1999; 20: 157-198.

20. WECKBECKER G, RAULF F, BODMER D, BRUNS C.: Indirect antiproliferative effect of the somatostatin analog octreotide on MIA PaCa-2 human pancreatic carcinoma in nude mice. Yale J Biol Med 1998; 70: 549-554.

21. LAMBERTS SW, VAN DER LELY A, DEHARDER WW, HOFLAND LJ.: Drug therapy: octreotide. New Eng J Med 1996; 334: 246-254.

22. FIGG WD, THIBAULT A, COOPER MR et al.: A phase I study of the somatostatin analogue somatuline in patients with metastatic hormone refractory prostate cancer. Cancer 1995; 15: 2159-2164.

23. MAULARD C, RICHAUD P, DROZ JP, JESSUELD D, DUFOUR-ESQUERRE F, HOUSSET M.: Phase I-II study of the somatostatin analogue lanreotide in hormone-refactory prostate cancer. Cancer Chemother Pharmacol 1995; 36: 259-262.

24. LOGOTHETIS CJ, HOSSAN EA, SMITH TL.: SMS 201-995 in the treatment of refractory prostatic carcinoma. Anticancer Res 1994; 14: 2731-2734.

25. BUSCAIL L, DELESQUE N, ESTEVE JP et al.: Stimulation of tyrosine phosphatase and inhibition of cell proliferation by somatostatin analogues: mediation by human somatostatin receptor subtypes SST1 and SST2. Proc Natl Acad Sci USA 1994; 91: 2315-2319.

26. PATEL YC, GREENWOOD MT, KENT G, PANETTA $\mathrm{R}$, SRIKANT CB.: Multiple gene transcripts of the somatostatin receptor SSTR2: tissue selective distribution and cAMP regulation. Biochem Biophys Res Commun 1993; 192: 288-294.

27. BUSCAIL L, SAINT-LAURENT N, CHASTRE E et al.: Loss of sst2 somatostatin receptor gene expression in human pancreatic and colorectal cancer. Cancer Res 1996; 56: 1823-1827.

28. ROCHAIX P, DELESQUE N, ESTEVE JP et al.: Gene therapy for pancreatic carcinoma: local and distant antitumor effects after somatostatin receptor sst2 gene transfer. Hum Gene Ther 1999; 10: 995-1008.

29. DELESQUE N, BUSCAIL L, ESTEVE JP et al.: sst2 somatostatin receptor expression reverses tumorigenicity of human pancreatic cancer cells. Cancer Res 1997; 57: 956-962.

30. TONKS NK, CHARBONNEAU H.: Protein tyrosine dephosphorylation and signal transduction. TIBS 1989; 14: 497-500.

31. FAUMAN EB, SAPER MA.: Structure and function of the protein tyrosine phosphatases. TIBS 1996; 21: 413-417.

32. TONKS NK, NEEL BG.: Combinatorial control of the specificity of protein tyrosine phosphatases. Curr Opin Cell Biol 2001; 13: 182-195. 
33. SUN H, TONKS NK.: The coordinated action of protein tyrosine phosphatases and kinases in cell signaling. TIBS 1994; 19: 480-485.

34. KEYSE S.M.: Protein phosphatases and the regulation of mitogen activated protein kinase signaling. Curr Opin Cell Biol 2000; 12: 186-192.

35. WISHART MJ, TAYLOR GS, SLAMA JT, DIXON JE.: PTEN and myotubularion phosphoinositide phosphatases: bringing bioinformatics to the lab bench. Curr Opin Cell Biol 2001; 13: 172-181.

36. BLONDEAU F, LAPORTE J, BODIN S, SUPERTIFURGA G, PAYRASTRE B, MANDEL J.: Myorubularin, a phosphatase deficient in myotubular myopathy, acts on phosphatidylinositol 3-kinase and phosphatidylinositol 3-phosphate pathway. Hum Mol Genet 2000; 9: 2223-2229.

37. SADOWSKI Y, STONE JC, PAWSON T.: A non catalytic domain conserved among cytoplasmic protein-tyrosine kinases modifies the kinase function and transforming activity of Fujinami sarcoma virus P130 gag-fps. Mol Cell Biol 1986; 6: 43964408.

38. SHEN S, BASTIEN L, POSNER BI, CHRETIEN P.: A protein-tyrosine phosphatase with sequence similarity to the SH2 domain of the protein-tyrosine kinases. Nature 1991; 352: 736-739.

39. PLUTZKY J, NEEL BG, ROSENBERG RD.: Isolation of a src homology 2-containing tyrosine phosphatase. Proc atl Acad Sci USA 1992; 89: 1123-1127.

40. MATTHEWS RJ, BOWNE DB, FLORES E, THOMAS ML.: Characterization of hematopoietic intracellular protein tyrosine phosphatases: description of a phosphatase containing an SH2 domain and another enriched in proline-, glutamic acid-, serine-, and threonine-rich sequences. Mol Cell Biol 1992; 12: 2396-2405.

41. VOGEL W, LAMMERS R, HUANG J, ULLRICH A.: Activation of a phosphotyrosine phosphatase by tyrosine phosphorylation. Science 1993; 259: 1611-1614.

42. AHMAN S, BANVILLE D, ZHAO Z, FISCHER EH, SHEN SH.: A widely expressed human protein tyrosine phosphatase containing src homology 2 domains. Proc Natl Acad USA 1994; 90: 2197-2201.

43. FREEMAN JRRM, PLUTZKY J, NEEL BG.: Identification of a human src homology 2-containing protein tyrosine-phosphatase. Proc Natl Acad Sci USA 1992; 89: 11239-11243.

44. FENG GS, HUI CC, PAWSON T.: SH2-containing phosphotyrosine phosphatase as a target of protein tyrosine kinase. Science 1993; 259: 1607-1611.

45. ADACHI M, SEKIYA M, MIYACHI T et al.: Molecular cloning and sequencing of a novel protein-tyrosine phosphatase SH-PTP3 with sequence similarity to the src-homology 2 region. FEBS Let 1993; 314: 335-339.

46. MATOZAKI T, UCHIDA T, FUJIOKA Y, KASUGA M.: Src kinase tyrosine phosphorylates PTP1C, a protein tyrosine phosphatase containing Src homology-2 domains that down-regulates cell proliferation. Biochem Biophys Res Commun 1994; 204: 871-881.

47. MATOZAKI T, KASUGA M.: Roles of protein-tyrosine phosphatases in growth factor signaling. Cell Signal 1996; 8: 13-19.
48. BANVILLE D, STOCCO R, SHEN SH.: Human protein tyrosine phosphatase 1C (PTPN6) gene structure: alternate promoter usage and exon skipping generate multiple transcripts. Genomics 1995; 27: 165-173.

49. SHULTZ LD, GREEN MC.: Motheaten, an immunodeficient mutant of the mouse. II. Depressed immune competence and elevated serum immunoglobulins. $J$ Immunol 1976; 116: 936-943.

50. SHULTZ LD, RAJAN TV, GREINER DL.: Severe defects in immunity and hematopoietic caused by SHP-1 protein-tyrosine phosphatase deficiency. Trends Biotechnol 1997; 15: 302-307.

51. SCHWARTZ MA, BARON V.: Interactions between mitogenic stimuli, or, a thousand and one connections. Curr Opin Cell Biol 1999; 11: 197-202.

52. TOMIC S, GREISER U, LAMMERS $\mathrm{R}$ et al.: Association of SH2 domain protein tyrosine phosphatases with the epidermal growth factor receptor in human tumor cells. Phosphatidic acid activates receptor dephosphorylation by PTP1C. J Biol Chem 1995; 270: 21277-21284.

53. TENEV T, KEILHACK H, TOMIC S et al.: Both SH2 domain are involved in interaction of SHP-1 with the epidermal growth factor receptor but cannot confer receptor-directed activity to SHP-1/SHP-1 chimera. J Biol Chem 1997; 272: 5966-5973.

54. VAMBUTAS V, KAPLAN DR, SELLS MA, CHERNOFF J.: Nerve growth factor stimulates tyrosine phosphorylation and activation of Src homologycontaining protein-tyrosine phosphatase 1 in PC12 cells. J Biol Chem 1995; 270: 25629-25633.

55. UCHIDA T, MATOZAKI $\mathrm{T}$, NOGUCHI $\mathrm{T}$ et al: Insulin stimulates the phosphorylation of $\mathrm{Tyr}^{538}$ and the catalytic activity of PTP1C, a protein tyrosine phosphatase with Src homology-2 domains. $J$ Biol Chem 1994; 269: 12220-12228.

56. MACHIDE M, KAMITORI K, KOHSAKA S.: Hepatocyte growth factor-induced differential activation of phospholipase $\mathrm{C} \gamma 1$ and phosphatidylinositol 3-kinase is regulated by tyrosine phosphatase SHP-1 in astrocytes. $J$ Biol Chem 2000; 275: 31392-31398.

57. YI T, MUI ALF, KRISTAL G, IHLE JN.: Hematopoietic cell phosphatase associates with the interleukin-3 (IL-3) receptor b chain and downregulates IL-3 -induced tyrosine phosphorylation and mitogenesis. Mol Cell Biol 1993; 13: 75777585 .

58. KLINGMÜLLER U, LORENZ U, CANTLEY LC, NEEL BG, LODISH HF.: Specific recruitment of SH-PTP1 to the erythropoietin receptor causes inactivation of JAK2 and termination of proliferative signals. Cell 1995; 80: 729-738.

59. DAVID M, CHEN HE, LING L, GOELZ S, LARNER AC, NEEL BG.: Differential regulation of the $a / b$ interferon-stimulated Jak/Stat pathway by the SH2-domain containing tyrosine phosphatase SHPTP1. Mol Cell Biol 1995; 15: 7050-7058.

60. JIAO H, BERRADA K, YANG W, TABRIZI M, PLATANIAS LC, YI T.: Direct association with and dephosphorylation of Jak2 kinase by the SH2domain-containing protein tyrosine phosphatase SHP-1. Mol Cell Biol 1996; 16: 6985-6992. 
61. BEDECS K, ELBAZ N, SUTREN M et al.: Angiotensin II type 2 mediate inhibition of mitogenactivated protein kinase cascade and functional activation of SHP-1 tyrosine phosphatase. Biochem $J$ 1997; 325: 449-454.

62. LÓPEZ F, ESTEVE JP, BUSCAIL L y cols.: The tyrosine phosphatase SHP-1 associates with the sst2 somatostatin receptor and is an essential component of sst2-mediated inhibitory growth signaling. $J$ Biol Chem 1997; 272: 24448-24454.

63. ZAPATA P, ROPERO RM, VALENCIA AM y cols.: Autocrine regulation of $\mathrm{PC} 3$ prostate cell proliferation by somatostatin through the modulation of SHP-1. $J$ Clin Endocrinol Metabolism 2002; 87: 915-926.

64. SU L, ZHAO ZJ, BOUCHARD P, BANVILLE D, FISCHER EH, KREBS EG, SHEN S.: Positive effect of overexpressed protein-tyrosine phosphatase PTP1C on mitogen-activated signaling in 293 cells. $J$ Biol Chem 1996; 271: 10385-10390.

65. FLORIO T, YAO H, CAREY KD, DILLON TJ, STORK PJS.: Somatostatin activation of mitogen-activated protein kinase via somatostatin receptor 1 (SSTR1). Mol Endoc 1999; 13: 24-37.

66. SHARMA K, PATEL YC, SRIKANT CB.: C-terminal region of human somatostatin receptor 5 is required for induction of $\mathrm{Rb}$ and $\mathrm{G}_{1}$ cell cycle arrest. Mol Endoc 1999; 13: 82-90.

67. REARDON DB, DENT P, WOOD SL, KONG T, STURGILL TW.: Activation in vitro of somatostatin receptor subtypes 2,3 , or 4 stimulates protein tyrosine phosphatase activity in membranes from transfected ras- transformed NIH 3T3 cells: coexpression with catalitically inactive SHP-2 blocks responsiveness. Mol Endoc 1997; 11: 1062-1069.

68. ZEGGARI M, ESTEVE JP, RAULY I y cols.: Co-purification of a protein tyrosine phosphatase with activated somatostatin receptors from rat pancreatic acinar membranes. Biochem J 1994; 303: 441-448.

69. BOUSQUET C, DELESQUE N, LÓPEZ F y cols.: sst2 somatostatin receptor mediates negative regulation of insulin receptor signaling through the tyrosine phosphatase SHP-1. J Biol Chem 1998; 273: 7099-7106.

70. RAULY I, SAINT-LAURENT N, DELESQUE N y cols.: Induction of a negative autocrine loop by expression of sst2 somatostatin receptor in $\mathrm{NIH}$ 3T3 cells. J Clin Invest 1996; 97: 1874-1883.

71. PAGĖS P, BENALI N, SAINT-LAURENT N y cols.: sst2 somatostatin receptor mediates cell cycle arrest and induction of p27 ${ }^{\mathrm{Kipl}}$. J Biol Chem 1999; 274: $15186-15193$.

72. LÓPEZ F, FERJOUX G, CORDELIER P y cols.: Neuronal nitric oxide synthase is a SHP-1 substrate involved in sst2 somatostatin receptor growth inhibitory signaling. FASEB $J 2001$.

73. MEDINA DL, VELASCO JA, SANTISTEBAN P.: Somatostatin is expressed in FRTL-5 thyroid cells and prevents thyrotropin-mediated down-regulation of the cyclin-dependent kinase inhibitor p27kipl. Endocrinology 1999; 140: 87-95.

74. MEDINA DL, TORO MJ, SANTISTEBAN P.: Somatostatin interferes with thyrotropin-induced $\mathrm{G}_{1}-\mathrm{S}$ transition mediated by cAMP-dependent protein kinase and phosphatidylinositol 3-kinase. $J$ Biol Chem 2000; 275: 15549-15556.
75. SRIKANT CB, SHEN S.: Octapeptide somatostatin analog SMS 201-995 induces translocation of intracellular PTP1C to membranes in MCF-7 human breast adenocarcinoma cells. Endocrinology 1996; 137: 3461-3468.

76. SHARMA K, PATEL YC, SRIKANT CB.: Subtype selective induction of wild type p53 and apoptosis, but not cell cycle arrest, by human somatostatin receptor 3. Mol Endoc 1996; 10: 1688-1696.

77. SHARMA K, SRIKANT CB.: Induction of wild-type p53, Bax, and acid endonuclease during somatostatin-signaled apoptosis in MCF-7 human breast cancer cells. Int $J$ Cancer 1998; 76: 259-266.

78. LIU D, MARTINO G, THANGARAJU M y cols.: Caspase-8-mediated intracellular acidification precedes mitochondrial dysfunction in somatostatininduced apoptosis. J Biol Chem 2000; 275: 92449250.

79. SHARMA K, SRIKANT CB.: G protein coupled receptor signaled apoptosis is associated with activation of a cation insensitive acidic endonuclease and intracellular acidification. Biochem Biophys Res Commun 1998; 242: 134-140.

80. THANGARAJU M, SHARMA K, LEBER B, ANDREWS DW, SHEN S, SRIKANT CB.: Regulation of acidification and apoptosis by SHP-1 and Bcl-2. $J$ Biol Chem 1999; 274: 29549-29557.

81. THANGARAJU M, SHARMA K, LIU D, SHEN SH, SRIKANT CB.: Interdependent regulation of intracellular acification and SHP-1 in apoptosis. Cancer Res 1999; 59: 1649-1654.

82. DI SANT'AGNESE PA, DE MESY JENSEN KL.: Somatostatin and/or somatostatin like immunoreactive endocrine-paracrine cells in the human prostate gland. Arch Pathol Lab Med 1984; 108: 693-696.

83. PINSKI J, SCHALLY AV, HALMOS G, SZEPESHAZI K.: Effect of somatostatin analog RC-160 and bombesin/gastrin releasing peptide antagonist RC3095 on growth of $\mathrm{PC}-3$ human prostate cancer xenografts in nude mice. Int $J$ Cancer 1993; 55: 963-967.

84. VERHELST J, DE LONGUEVILLE M, ONGENA P, DENIS L, MAHLER C.: Octreotide in advanced prostatic cancer relapsing under hormonal treatment. Acta Urol Belg 1994; 62: 83-88.

85. VAINAS G, PASAITOU V, GALAKTIDOU G y cols.: The role of somatostatin analogues incomplete antiandrogen treatment in patients with prostatic carcinoma. $J$ Exp Clin Cancer Res 1997; 16: 119-126.

86. BERRUTI A, DOGLIOTTI L, MOSCA A y cols.: Effects of the somatostatin analog lanreotide on the circulating levels of chromogranin-A, prostate-specific antigen and insulin-like growth factor-1 in advanced prostate cancer patients. Prostate 2001; 47: 205-211.

87. REUBI JC, WASER B, SCHAER J, MARKWALDER R.: Somatostatin receptors in human prostate and prostate cancer. J Clin Endocrinol Metab 1995; 80: 2806-2814.

88. SUNISI AA, BELLASTELLA A, PREZIOSO D y cols.: Different expression patterns of somatostatin receptor subtypes in cultured epithelial cells from human normal prostate and prostate cancer. J Clin Endocrinol Metab 1997; 82: 2566-2569. 
89. HALMOS G, SCHALLY AV, SUN B, DAVIS R, BOSTWICK DG, PLONOWSKI A.: High expression of somatostatin receptors and messenger ribonucleic acid for its receptor subtypes in organ-confined and locally advanced human prostate cancers. $J$ Clin Endocrinol Metab 2000; 85: 2564-2571.

90. BREVINI TA, BIANCHI R, MOTTA M.: Direct inhibitory effect of somatostatin on the growth of the human prostatic cancer cell line LNCaP: possible mechanism of action. $J$ Clin Endocinol Metab 1993; 77: 626-631.

91. VALENCIA AM, OLIVA JL, ANGULO JC, PRIETO JC, COLÁS B.: Identification of PTP1C in prostate tumor cells. Regulation by EGF. 92nd Annual Meeting Amer. Urolog. Assoc., New Orleans, Louisiana (USA) 1997.

92. LÓPEZ JI, ANGULO J, COLÁS B y cols.: Identification of SHP-1 in the prostate and its possible implication in the development and progression of prostate cancer. 91st Annual Meeting of the United States and Canadian Academy of Pathology, Chicago, IL, february 23 to march 1, 2002.

93. ZAPATA P, ROPERO RM, LÓPEZ-RUIZ MP, LÓPEZ JI, ANGULO J, COLAS B.: Somatostatina y cáncer de próstata. Revisiones en Urología 2000; 1: 7-16.

94. VALENCIA AM, OLIVA JL, BODEGA G y cols.: Identification of a protein-tyrosine phosphatase (SHP1) different from that associated with acid phosphatase in rat prostate. FEBS Let 1997; 406: $42-48$.

95. FLORIO T, THELLUNG S, ARENA S, CORSARO A, BAJETTO A, SCHETTINI G, STORK PJS.: Somatostatin receptor 1 (SSTR1)-mediated inhibition of cell proliferation correlates with the activation of the MAP kinase cascade: role of the phosphotyrosine phosphatase SHP-2. J Physiol 2000; 94: 239-250.
96. DOUZIECH N, CALVO E, COULOMBE $Z$ et al.: Inhibitory and stimulatory effects of somatostatin on two human pancreatic cancer cell lines: a primary role for tyrosine phosphatase SHP-1. Endocrinology 1999; 140: 765-777.

97. KOSSEV PM, RAGHUNATH PN, BAGG A, SCHUSTER S, TOMASZEWSKI JE, WASIK NA.: SHP-1 expression by malignant small B-cell lymphomas reflects the maturation stage of their normal B-cell counterparts. Am J Surg Pathol 2001; 25: 949-955.

98. ZHANG J, SOMANI A-K, SIMINOVITCH KA.: Roles of the SHP-1 tyrosine phosphatase in the negative regulation of cell signaling. Semin Immunol 2000; 12: 361-378.

99. DELIBRIAS CC, FLOETTMANN JE, ROWE M, FEARON DT.: Down regulated expression of SHP1 in Burkitt lymphomas and germinal center B lymphocytes. J Exp Med 1997; 186: 1575-1583.

100. WICKREMA A, CHEN F, NAMIN F, YI T et al.: Defective expression of SHP-1 phosphatase in polycythemia vera. Exp Hematol 1999; 27: 1124-1132.

101. BENALI N, CORDELIER P, CALISE D, PAGĖS P, ROCHAIX P, NAGY A, ESTEVE JP, POUR PM, SCHALLY AV, VAYSSE N, SUSINI C, BUSCAIL L.: Inhibition of growth and metastatic progression of pancreatic carcinoma in hamster after somatostatin receptor subtype 2 (sst2) gene expression and administration of cytotoxic somatostatin analog AN-238. Proc Natl Acad Sci USA 2000; 97: 9180-9185.

Dr. Javier C. Angulo

Servicio de Urología. Hospital Príncipe de Asturias Ctra. Acalá-Meco, s/n

28805 Alcalá de Henares (Madrid)

(Trabajo recibido el 7 octubre de 2002) 